\title{
Uncongenial congeners
}

\section{二日酔いをめぐる俗信の検証}

\section{Andrew Mitchinson}

Nature Vol. 462(992)/24/31 December 2009

どんな酒でも飲みすぎれば二日酔いになるものだが、一般 に、バーボンなどの濃い色をした酒は、ウォツカなどの無色 の酒に比べて、ひどい二日酔いになりやすいと信じられてい る。Damaris Rohsenow らは最近、この俗信を実験によっ て証明した (D.J.Rohsenow et al. Alcoholism Clin. Exp. Res. doi: 10.1111/j.1530-0277.2009.01116.x; 2009)。ま た、これらのアルコール飲料が引き起こす二日酔いが、集中 力の持続とスピードを要する課題の遂行能力を低下させるこ と、そして、課題遂行能力の低下は酒の色ではなく二日酔い の重さと相関していることも明らかにした。

アルコール飲料の色はコンジナーに由来していることが多 い。コンジナーとは、発酵の過程で形成されるアルコール (エ タノール ) 以外の化合物のことで、例えば、バーボンにはウォ ッカの 37 倍の量のコンジナーが含まれている。二日醉いの 諸症状は主としてエタノールによって引き起こされるが、コ
ンジナーはそれを悪化させると考えられている。

Rohsenowらは、この理論を対照試験により検証した。 被験者はまず、血中アルコール濃度が酩酊レベルに達するま でウォツカまたはバーボンを飲んだ。そして翌日、症状に基 づく尺度を使って二日酔いの程度を定量化したうえで、ス ピードや集中力の持続を要する課題の遂行能力がテストされ た。アルコールは睡眠の質と持続時間にも影響を及ぼすので、 著者らはこれらの影響も監視した。

その結果、バーボンによる二日酔いは、ウォツカによる二 日酔いよりも重いことが実際に確認された。また、すべての 被験者が、プラセボ（カフェイン抜きのコーラ）を摂取した ときょりもアルコールを摂取したときのほうが、眠りが浅く、 とぎれとぎれになっていた。しかし、睡眠や翌日の課題遂行 能力に与えた影響の大きさは、バーボンもウォツカも変わら なかった。さらに、アルコールによる睡眠障害の程度は、二 日酔いの重さと相関していたが、課題遂行能力の低下の原因 とはなっていなかった。

この研究の被験者は健康な若者だったので、高齢者やアル コール依存者では違った反応がみられた可能性がある。それ でも、著者らが指摘するように、これらの知見は高度な安全 性が求められる職業に従事する人々には大いに参考になるだ ろう。我々も、飲酒の翌朝にどうしてああいう感じになるの かを知ることができた。（三枝小夜子 訳） 